following motion was moved by Prof. Opik, seconded by Prof. Boothroyd, and carried:

"Commission 22 considers that it is not desirable that Comets should be joined to their subject."

The Report of the Commission was presented for discussion, and approved with some minor additions. The following resolution moved by Prof. Öpik, and seconded by Dr Fisher, was carried for submission to the General Assembly:

"The Union thinks that it is very desirable that the activity of the Meteor Expedition in Arizona be continued for a second year, to get a more complete check on the annual distribution of meteoric activity, and to fill out gaps produced by clouds and moonlight during the first year."

Dr Bosler gave some interesting details about the probable location of the Chinguetti meteoric mass, and discussed the possibility of recovering it, which appears to be considerable. The President pointed out the great interest of the study of this meteor, also on theoretical grounds.

Three suggestions contained in a letter to the Commission from Messrs J. E. Gedal, G. M. B. Dobson and Prof. Strömgren, were referred to the President for further consideration.

The Commission voted the following resolution, moved by $\mathrm{Dr}$ Fisher and seconded by Dr Bosler, for submission to the General Assembly:

"The Union express the opinion that it would be highly desirable to rediscover and to study completely the great so-called Chinguetti meteoric mass in the Adrar, North Africa. They very specially draw the attention of the French Government to the urgent necessity for organizing a scientific expedition entrusted with this study. Any further delay would be such as to render the exploration of this interesting meteorite much more difficult."

The following resolution, moved by the President and seconded by Dr Fisher, was also voted for submission to the General Assembly:

"The Union expresses the wish that the Government of the U.S.S.R. organize as soon as possible a fully equipped expedition to explore the region in Siberia of the great fall of June 30 , Ig08."

Dr Harlow Shapley explained the plan of meteoric research taken up at the Harvard College Observatory, and introduced Prof. Öpik, who gave a comprehensive account of the methods devised and used in the Arizona expedition, and of the preliminary results derived from the 20,000 meteors observed during the first year of this campaign.

The President described the attempts made to locate the great Arizona meteor, or meteors, and the results to be expected from the exploration of large meteoric masses.

\title{
Commission 23. (CARTE dU Ciel.)
}

President: M. Esclangon.

SeCRETARY: M. K. Hujer.

M. le Président rend hommage à ceux de ses membres que la Commission a perdus depuis sa précédente réunion: son éminent Président Turner, le $\mathrm{P}$. Hagen et M. Cosserat.

Il rend succinctement compte de l'état des travaux du Catalogue et de la Carte, et fait ressortir les notables progrès effectués depuis le dernier Rapport. 
D’une manière générale, le Catalogue est en bonne voie, sauf pour quelques zones qui se heurtent à d'importantes difficultés. De ce nombre sont la zone primitivement attribuée à Potsdam et reprise par Oxford et Hyderabad, et la partie de la zone de Perth dont Edimbourg a assumé les mesures et la publication. Une discussion s'engage sur les moyens d'aider ces observatoires à mener à bien leur entreprise. Ces moyens se raménent à l'attribution par l'Union de subventions destinées à couvrir les frais d'impressions. La discussion, à laquelle Sir Frank Dyson prend une grande part, aboutit au vœu suivant: "La Commission émet le vou que la subvention annuelle de $£ 300$ accordée par l'Assemblée Générale de I928 comme contribution aux frais d'impression du Catalogue photographique soit prolongée jusqu'à la Réunion suivante de l'Union."

Sur la proposition de Sir Frank Dyson, basée sur les conditions dans lesquelles se poursuivent les travaux dans les Observatoires de Hyderabad, Oxford et Edimbourg, la Commission décide que les sommes provenant des subventions de l'Union devront être employées dans l'ordre de préférence suivant: Hyderabad, Edimbourg, Oxford.

M. le Président appelle ensuite l'attention sur les Observatoires de Melbourne et de Sydney qui sont aux prises avec de grandes difficultés et qui, de plus, sont menacés d'être supprimés. Cette situation fait l'objet d'un échange de vues qui ne conduit à aucune conclusion en raison de l'incertitude de la situation.

M. Lagarde donne des indications sur l'état de la Carte qui est bien moins avancée que le Catalogue mais a été cependant l'objet d'importants travaux.

M. Baillaud fait ressortir le grand intérêt de la Carte qui a été, à l'origine, le principal but de l'entreprise et ne doit pas être négligée. Si on ne peut, pour le moment, l'exécuter au complet, on doit tout au moins exécuter la région de la Voie lactée qui est d'une importance toute particulière en ce qui concerne les études de statistique ayant pour objet la répartition des grandeurs stellaires et pour but la détermination de la forme de la Voie lactée dans l'espace. M. le Président indique que ce point de vue a déjà été signalé et que, notamment, il a fait l'objet d'une communication détaillée de $M$. Mineur à la réunion du Comité national français d'astronomie en juillet I93I.

En conclusion, sur la proposition de M. Baillaud, la Commission recommande aux observatoires engagés dans l'entreprise de ne pas abandonner la prise des clichés de la série de la Carte et de s'efforcer de les reproduire par l'héliogravure, tout au moins dans la région de la. Voie lactée.

\section{Commission 24. (Stellar Parallaxes and Proper Motions.)}

President: Prof. S. A. Mitchell.

SECRETARY: Prof. F. Slocum.

There were two meetings of the Commission. The first meeting was devoted to an informal discussion of programmes for parallax work. The second session was devoted to a discussion of systematic errors. The President gave a brief summary of the two latest determinations of the systematic errors of trigonometric parallaxes, by Schlesinger (parallaxes published to I924) and by van Maanen (parallaxes to I927). Both investigators had used the same basis of comparison, namely, the Mt Wilson spectroscopic parallaxes, and both had made the same fundamental assumption, namely, that the systematic errors of the spectroscopic parallaxes depending on right ascension were negligible. In carrying out the comparisons, the 